\title{
EL PAPEL DE LA ESTADÍSTICA EN LA METODOLOGÍA SEIS SIGMA. UNA PROPUESTA DE ACTUACIÓN EN SERVICIOS SANITARIOS / THE KEY ROLE OF STATISTICAL METHODS IN SIX-SIGMA: A PROPOSAL OF IMPLEMENTATION IN HEALTH CARE SER VICES
}

\author{
Carmen Huerga Castro ${ }^{1}$ \\ carmen.huerga@unileon.es \\ Julio I. Abad González ${ }^{1}$ \\ julio.abad@unileon.es \\ Pilar Blanco Alonso ${ }^{1}$ \\ pilar.blanco@unileon.es \\ Universidad de León
}

\section{Resumen}

La metodología seis sigma es un programa de mejora continua de la calidad que, en base a hechos y datos, persigue reducir errores y avanzar hacia altos objetivos de calidad. Ofrece un enfoque estructurado, analítico y racional para el establecimiento de proyectos de mejora acordes con los objetivos planteados. Si bien la popularidad del seis sigma se deriva de su aplicación en los procesos productivos del sector industrial, cada vez está más extendida su aplicación en el sector servicios y, por ende, en los servicios sanitarios donde la "satisfacción del cliente" adquiere una relevancia vital.

La aplicación de seis sigma requiere el uso de un amplio abanico de herramientas estadísticas, de hecho, el término sigma representa la desviación típica de una distribución y es el factor clave para conocer la variabilidad de la misma. Por ello, en este trabajo señalamos las herramientas más apropiadas en cada etapa o fase de implementación del seis sigma (definir, medir, analizar, mejorar y controlar) y presentamos una propuesta de aplicación en un servicio sanitario.

Palabras clave: Seis sigma; Control estadístico de la calidad; Senvicio sanitario.

\section{Abstract}

Six-Sigma is a strategy for continuous quality improvement based on facts and data that attempts to reach higher quality standards and lower number of defects. Six-Sigma provides a structured,

${ }^{1}$ Facultad de Ciencias Económicas y Empresariales, Departamento de Economía y Estadística, Área de Estadística e Investigación Operativa. Universidad de León, Campus de Vegazana, 24071-León (España). 
analytic and rational approach that allows the implementation of quality improvement projects according to the planned objectives. Although its current popularity is mainly due to its widespread implementation in the industrial sector, it is also being increasingly used in the services sector, such as in health care services, where the customer's satisfaction has an even more crucial relevance. Six-Sigma involves the use of a wide range of statistical tools; in fact, the term sigma means standard deviation, which is a key measure of the distribution's variability. In this paper the statistical tools more suitable for each phase of Six-Sigma's adoption are presented as well a proposal of its adoption in health care services.

Keywords: Six-Sigma; Statistical quality control; Health care services.

\section{INTRODUCCIÓN}

Seis sigma se inicia en Motorola a finales de la década de 1980 como una estrategia de mejora de la calidad, adoptada para enfrentarse a una crisis en la calidad de sus productos. Las aportaciones de Bill Smith y Mikel Harry impulsaron una metodología que requiere el uso de herramientas estadísticas, y cuyo objetivo consiste en eliminar la variabilidad de los procesos y producir los resultados esperados, con el mínimo número de defectos, bajos costes y máxima satisfacción del cliente. Esta filosofía contrasta con la forma tradicional de asegurar la calidad, basada únicamente en la inspección final. A partir de esta propuesta inicial, que llevó a Motorola a ganar el prestigioso premio de calidad Baldrige en 1988, la metodología seis sigma ha evolucionado, pasando de ser una simple herramienta de medición de defectos, a una filosofía de mejora de calidad que se basa en hechos y datos y encuentra en la Estadística valiosas herramientas de análisis. Seis sigma se apoya en medidas objetivas y pone la atención en los resultados a corto plazo para conseguir mejoras a más largo plazo.

El nivel sigma está directamente relacionado con la cantidad de oportunidades de defecto que puede presentar un producto o servicio. De hecho, el objetivo del seis sigma es lograr procesos que no tengan más de 3,4 defectos por millón de oportunidades.

\section{INTRODUCTION}

Six-Sigma originated at Motorola Inc. in the late 1980 s as a quality improvement strategy designed to deal with a quality crisis in their products. Bill Smith and Mike Harry's contributions fostered a strategy that, by using statistical tools, aimed to reduce processes variability and achieve the expected results with minimum defects, low costs and maximum customers' satisfaction. Six-Sigma contrasts the traditional way of quality assurance, just based on a final inspection. From Motorola's initial proposal, awarded in 1988 with the prestigious Malcolm Baldrige National Quality Award, Six-Sigma has evolved and become a philosophy of continuous quality improvement that, based on objective measures and using different statistical tools, focus on short-term results in order to achieve long-term improvements. But SixSigma is closely related to the number of nonconformities per million opportunities of a product or service. In fact, Six-Sigma's goal is to achieve processes with a level of performance equating 3.4 nonconformities per million opportunities. 
Es evidente que las consecuencias que un defecto puede acarrear, difieren según el tipo de producto o servicio, y aunque no necesariamente todos los procesos deben operar a nivel seis sigma, en las empresas que prestan servicios de salud, buscar un nivel de calidad seis sigma debería ser un objetivo primordial.

La atención sanitaria puede entenderse como un proceso de producción. Cuando un paciente entra en un sistema sanitario, desencadena un proceso de producción que debe satisfacer sus necesidades tanto como sea posible (Vuori, 1996: 13). Según afirma Vuori es posible identificar algunos componentes básicos del proceso de la atención al paciente: realización de la historia clínica, diagnóstico, tratamiento y seguimiento, aunque el contenido real de estos componentes depende del paciente y sus necesidades.

La metodología seis sigma en el área de la salud comenzó en Estados Unidos a finales de la década de 1990. En 1998 el Dr. Chassin publicó un artículo titulado "Is Health Carey Ready for Six Sigma Quality?" donde expone un análisis de las causas subyacentes de los problemas de calidad y sugiere la adopción de métodos seis sigma dentro de un marco global para el cambio. Encontramos también propuestas de aplicación de la metodología seis sigma en hospitales chilenos (Ramírez, Pinto, Serpell y Enberg, 2007) en un enfoque donde se plantean las ventajas y consecuencias de incorporar esta metodología en el sector servicios y más concretamente en el de la salud. Otras aplicaciones interesantes muestran las posibilidades para reducir errores médicos (Buck, 2001) y del mismo modo en los hospitales alemanes se ha implementado esta metodología en casos concretos del departamento de enfermería (Van den Heuvel, Doess y Vermaat, 2004). Por su parte, Jiménez et al. (2007) la aplican en la mejora de la logística sanitaria.
Obviously, the consequences of nonconformities depend on the kind of products or services, and maybe performing at a Six-Sigma level could not be possible in every process; however, achieving this quality level should be a main goal for the health care companies.

In fact, health care could be considered as a production process: when a patient contacts the health care system, a production process oriented to meet their needs as much as possible starts up (Vuori, 1996: 13). According to Vuori, it is possible to identify some basic components in the patient attendance process: medical record writing, diagnosis, treatment and followup, though the actual content of these components depend on the patient and their needs.

It was in the late 1990s when Six-Sigma started to be implemented in Health Care companies in the United States. An analysis of the underlying causes for medical errors and a proposal for the implementation of Six-Sigma methods in a global improvement framework is presented in 1998 Chassin's paper Is health care ready for Six Sigma quality? Ramirez, Pinto, Serpell and Enberg (2007) discuss the advantages and consequences derived from the adoption of Six-Sigma methods in the services sector in general, and in health care services in particular, and suggest its adoption in Chilean Hospitals. Buck (2001) focuses on the possibilities of Six-Sigma in reducing medical errors, while Van den Heuvel, Doess and Vermaat (2004) describe its implementation in the nursery department of a Dutch hospital, and Jiménez et al. (2007) propose their adoption to improve healthcare logistics. 
Esto demuestra que las organizaciones que prestan sus servicios en el sector de la salud no son ajenas a los principios del seis sigma y buscan nuevas formas para mejorar sus procesos y reducir la insatisfacción de los pacientes, aunque ello requiere el compromiso de todos los agentes implicados (médicos, enfermeras, administradores, personal de apoyo, etc.). La puesta en marcha de un plan de trabajo seis sigma en un servicio de salud lleva consigo una buena planificación e infraestructura. El punto de partida es el reconocimiento y la localización de los problemas para saber qué proyectos hay que abordar y cómo llevarlos a cabo. En esta tarea, la metodología que se propone ofrece un marco eficaz y un nuevo enfoque perfectamente aplicable en la asistencia sanitaria.

Presentamos a continuación los conceptos y las etapas que integran esta metodología, así como la potencia de las técnicas estadísticas en la consecución de los objetivos de calidad mediante una propuesta de actuación en el ámbito sanitario.

\section{LA METODOLOGÍA SEIS SIGMA: CONCEPTO, CARACTERÍSTICAS $Y$ FASES}

Desde el punto de vista estadístico sigma representa la desviación típica $(\sigma)$ de un conjunto de datos, es decir la dispersión respecto al valor medio. En el contexto que nos ocupa sigma representa la variación existente en un proceso en relación con las especificaciones o requerimientos establecidos. La magnitud de sigma está relacionada directamente con el número de unidades defectuosas (que no cumplen las especificaciones), de modo que si la desviación es pequeña habrá pocos valores fuera de las especificaciones.
All this proves that companies and institutions in the health care sector are not alien to Six-Sigma principles, i.e. they search new ways of improving their processes and increase their patients' satisfaction, and that requires the commitment of the whole organization (physicians, nurses, managerial and administrative staff, etc.).

Moreover, the implementation of the SixSigma methodology in health services requires both planning and infrastructure. It should starts by detecting and spotting where are the problems in order to determine which projects should be developed and how to do it. For this purpose, this methodology provides with an effective framework and a new approach which could be perfectly applied in the health care area.

In the following sections, the concepts and phases integrating the Six-Sigma methodology are presented as well as an example of implementation in the health care context that illustrates the key role played by the statistical methods in the quality improvement.

\section{SIX-SIGMA: CONCEPT, FEATURES AND PHASES}

In statistical terms, sigma $(\sigma)$ represents the standard deviation of a data set, i.e. the dispersion of those data from their mean or average. In a production process, sigma stands for the actual variation of a process in terms of the established specifications or requirements. Sigma size is directly related to the number of nonconformities (those product units that do not meet the specifications), i.e. the lower sigma is, the less nonconformities will be. 
En la terminología de control de calidad, al hablar de seis sigma se está midiendo el número de sigmas que se incluyen dentro del intervalo definido por los límites de especificación superior e inferior; cuando sigma es pequeño mayor es el número de las mismas que caben dentro de las especificaciones $y$, en consecuencia, menor es el número de unidades defectuosas.

A partir de este concepto estadístico se ha desarrollado toda una filosofía de calidad enfocada a la mejora continua, mediante el análisis de los procesos y la puesta en marcha de métodos adecuados para medir y controlar su funcionamiento. Así, cuando se decide poner en marcha la metodología seis sigma lo que se pretende es minimizar defectos hasta tener como máximo 3,4 defectos por millón de oportunidades. Este objetivo se logra reduciendo la variación existente en los procesos, de modo que sean más predecibles y los productos o servicios que originan sean mejores.

Podemos resumir las características principales de esta metodología en las siguientes:

- Su objetivo es lograr productos y servicios de calidad

- Establece como prioridad al cliente.

- Se basa en hechos y datos, diseñando un esquema para recogerlos y analizarlos.

- Sus principios son aplicables tanto en los procesos productivos como en los servicios.

- Requiere la implicación, participación y compromiso de todo el personal implicado.

La puesta en marcha de la metodología seis sigma se lleva a cabo mediante el ciclo DMAMC (Definir, Medir, Analizar, Mejorar y Controlar).
In quality control, the term Six-Sigma refers to the number of standards deviations that are included between the lower and upper specification limits; if sigma is small, then a high number of standard deviations can be included between those limits and therefore, a lower number of nonconformities will be produced.

Based on this statistical concept, a global philosophy, focused on the continuous quality improvement through the analysis, measuring, monitoring and control of the performance of the processes, has been developed. In fact, Six-Sigma's goal is minimizing the number of defects and keeping it under a level of 3.4 nonconformities per million opportunities. This goal is achieved by reducing the inherent variation of the processes so that they become more predictable and the resulting quality of the products or services improves.

The main features of Six-Sigma strategy could be summarized in the following:

- It aims to achieve products and services with a high standard of quality.

- It is customer-oriented.

- Since it is based on facts and data, it provides with schemes to collect and analyse them.

- It can be applied both to products or services.

- It demands the implication, participation and commitment of the whole staff of the company.

The phases in applying Six-Sigma methodology are often referred to as Define-Measure-Analyse-Improve-Control (DMAIC): 
Definir. En esta primera etapa se plantea el problema, se especifica el objetivo o meta que se pretende alcanzar, y se identifican los elementos que intervienen en el proyecto.

Medir. En segundo lugar, se obtiene información sobre la situación actual del proceso que se evalúa, con el fin de detectar las casusas reales de los problemas.

Analizar. A partir de los datos, y usando métodos estadísticos, se procede a su análisis e interpretación.

Mejorar. Decidir y diseñar las acciones de mejora que hay que implementar para atacar las causas de los problemas de modo que el proceso alcance los resultados esperados.

Controlar. Realizar un seguimiento de las acciones de mejora y comprobar sus resultados.

\section{TÉCNICAS ESTADÍSTICAS EN LAS ETAPAS DEL SEIS SIGMA}

En cualquiera de las fases mencionadas se presentan problemas que requieren la utilización de la Estadística y de sus técnicas. En realidad, seis sigma se sustenta en los principios de calidad como la trilogía de Juran, la metodología de Deming (medir, analizar, mejorar y controlar), las siete herramientas de Ishikawa, el diseño robusto de Taguchi, los gráficos de control de Shewhart, los estudios de capacidad, los postulados de "cero defectos" de Crosby, así como en métodos estadísticos más o menos complejos del diseño experimental, del análisis de regresión, etc. El uso de estas herramientas en combinación con el software estadístico disponible en la actualidad resulta imprescindible para solucionar los problemas de calidad y avanzar en su mejora.
Define: the first step is to define the problem to be addressed, specifying the goals that are aimed, and identifying the elements involved in the project.

Measure: in the second step, information about the current situation of the evaluated process is gathered in order to detect the root causes of defects.

Analyse: in the third step, the data gathered in the previous step are analysed and interpreted by means of statistical tools.

Improve: in the fourth step, improvement actions are determined and designed in order to significantly reduce the defect levels of the process.

Control: in the last step, the improvement actions that have been adopted are followed up in order to check if their expected results have been actually achieved.

\section{STATISTICAL TOOLS IN THE SIX- SIGMA PHASES}

In any of the phases previously mentioned, situations requiring the application of statistical techniques may appear. In fact, Six-Sigma actually stands on quality principles such as Juran trilogy, Deming cycle (Plan-Do-Study-Adjust), Ishikawa seven basic tools of quality, Taguchi robust design method, Shewhart control charts, capability studies, Crosby zero defects postulate, as well as other statistical methods such as design of experiments or regression analysis. Therefore, in order to solve quality-related problems and promote quality improvements, the use of these tools by means of statistical software currently available becomes essential. 
Cada problema puede plantearse mediante la siguiente relación:

$$
Y=f\left(X_{1}, X_{2}, \ldots \ldots, X_{n}\right)
$$

donde $Y$ es la variable dependiente que se asocia con el resultado esperado mientras que los factores que influyen en el mismo son las variables independientes $X_{1}, X_{2}, \ldots \ldots, X_{n}$. Pero no todos los factores tienen la misma influencia e importancia, de ahí la necesidad de disponer de herramientas que permitan distinguir entre los muchos triviales y los pocos vitales.

En la metodología que propugna seis sigma se encuentran las bases para encontrar dicha ecuación. Para ello combina diferentes técnicas estadísticas con otras que no lo son estrictamente, como por ejemplo el QFD ${ }^{2}$ (Quality Function Deployment) y el FMEA ${ }^{3}$ (Failure Mode and Effects Analysis).

Sin ánimo de ser exhaustivos, la Tabla 1 recoge distintas técnicas utilizadas en la metodología seis sigma. Aunque las herramientas de tipo estadístico están presentes en prácticamente todas las fases, es evidente que en la fase de análisis resulta imprescindible el uso de la Estadística. Por otro lado, conviene señalar que una misma técnica o herramienta se puede utilizar en distintas fases.

\footnotetext{
${ }^{2}$ El QFD tiene como objetivo trasladar las necesidades de los clientes a requisitos y características de calidad creando procesos que puedan contribuir al aseguramiento de estas características. Se puede traducir como Despliegue de la Función de Calidad.

${ }^{3}$ El FMEA se utiliza para identificar, evaluar y prevenir los fallos y sus efectos en un producto o servicio. De este modo permite determinar qué características hay que controlar. Se puede traducir como Análisis Modal de Fallos y Efectos.
}

Any problem could be represented through the following relation:

$$
Y=f\left(X_{1}, X_{2}, \ldots \ldots, X_{n}\right)
$$

where $Y$ is the dependent variable represents a performance measure of the output and the influencing factors are represented by the independent variables $X_{1}, X_{2}, \ldots \ldots, X_{n}$. However, since not all the factors have the same influence or importance, it is vital to separate the vital few from the trivial many by using the appropriate methods.

Therefore, this equation can be determined by means of Six-Sigma tools, which include not only statistical methods but also other techniques such as Quality Function Deployment (QFD) ${ }^{4}$ or Failure Mode and Effects Analysis $(\mathrm{FMEA})^{5}$, being the most relevant those presented in Table 1. Although the statistical tools are used in almost every Six-Sigma phase (in fact, the same tool can be used in more than one phase), it is obvious that their use is particularly essential in the analysis phase.

\footnotetext{
${ }^{4}$ QFD aims to transform customers' needs into quality features and requirements by developing processes capable of assuring these features.

5 FMEA is used to identify, evaluate and prevent defects and their consequences in products or services and, eventually, to determine which features must be controlled.
} 
Tabla 1

\begin{tabular}{|c|c|c|}
\hline FASE & CONCEPTO & HERRAMIENTAS \\
\hline Definir & $\begin{array}{l}\text { Identificar procesos sobre los que } \\
\text { actuar, detallando las necesidades } \\
\text { de los clientes }\end{array}$ & $\begin{array}{l}\text {-QFD } \\
\text {-Diagrama de flujo } \\
\text {-FMEA }\end{array}$ \\
\hline Medir & $\begin{array}{l}\text { Desarrollar plan de recogida de } \\
\text { datos. Obtener información y medir } \\
\text { las características de calidad }\end{array}$ & $\begin{array}{l}\text {-Plantillas recogida de datos } \\
\text {-Muestreo estadístico } \\
\text {-FMEA } \\
\text {-Brainstorming }\end{array}$ \\
\hline Analizar & $\begin{array}{l}\text { Analizar la información para } \\
\text { determinar las causas de los } \\
\text { problemas }\end{array}$ & $\begin{array}{l}\text {-Histograma } \\
\text {-Gráfico de Pareto } \\
\text {-Diagrama causa-efecto } \\
\text {-Diagrama de dispersión } \\
\text {-Análisis de regresión } \\
\text {-Series temporales } \\
\text {-Pruebas de hipótesis } \\
\text {-Gráficos de control } \\
\text {-Estudios de capacidad y nivel sigma } \\
\text {-ANOVA }\end{array}$ \\
\hline Mejorar & $\begin{array}{l}\text { Buscar e implementar acciones de } \\
\text { mejora }\end{array}$ & $\begin{array}{l}\text {-Brainstorming } \\
\text {-Diseño de experimentos } \\
\text {-FMEA }\end{array}$ \\
\hline Controlar & $\begin{array}{l}\text { Comprobar y mantener la mejora. } \\
\text { Establecer plan de control }\end{array}$ & $\begin{array}{l}\text {-Gráficos de control } \\
\text {-Análisis de capacidad } \\
\text {-Determinación del nivel sigma del proceso }\end{array}$ \\
\hline
\end{tabular}

\section{Table 1}

\begin{tabular}{|c|c|c|}
\hline PHASE & CONCEPT & TOOLS \\
\hline Define & $\begin{array}{l}\text { Identify core processes and define } \\
\text { customer requirements }\end{array}$ & $\begin{array}{l}\text {-QFD } \\
\text {-Flux diagram } \\
\text {-FMEA }\end{array}$ \\
\hline Measure & $\begin{array}{l}\text { Gather information and measure } \\
\text { quality features following a previously } \\
\text { designed scheme }\end{array}$ & $\begin{array}{l}\text {-Data collection grids } \\
\text {-Statistical sampling } \\
\text {-FMEA } \\
\text {-Brainstorming }\end{array}$ \\
\hline Analyse & $\begin{array}{l}\text { Analyse the collected data in order to } \\
\text { determine the causes of the defects }\end{array}$ & $\begin{array}{l}\text {-Histogram } \\
\text {-Pareto chart } \\
\text {-Cause-effect diagram } \\
\text {-Scatter plot } \\
\text {-Regression analysis } \\
\text {-Time series analysis } \\
\text {-Hypothesis tests } \\
\text {-Control charts } \\
\text {-Capability analysis and sigma quality level calculation } \\
\text {-ANOVA }\end{array}$ \\
\hline Improve & $\begin{array}{l}\text { Design and implement improvement } \\
\text { actions }\end{array}$ & $\begin{array}{l}\text {-Brainstorming } \\
\text {-Design of experiments } \\
\text {-FMEA }\end{array}$ \\
\hline Control & $\begin{array}{l}\text { Check and ensure the improvements } \\
\text { are sustained by establishing control } \\
\text { plans }\end{array}$ & $\begin{array}{l}\text {-Control charts } \\
\text {-Capability analysis } \\
\text {-Calculation of the process' sigma quality level }\end{array}$ \\
\hline
\end{tabular}




\section{DETERMINACIÓN DEL NVEL SIGMA}

En el contexto que nos ocupa la evaluación de los procesos se realiza en base a los niveles de sigma: desde el nivel $1 \sigma$ hasta el nivel $6 \sigma$. Trataremos en este apartado de explicar cómo se traduce el nivel de calidad seis sigma en 3,4 defectos por millón.

Generalmente las características de calidad estudiadas en los procesos se ajustan a un modelo probabilístico normal $y$, por lo tanto, los datos originados se distribuyen respecto a un valor central (media) con una dispersión que se mide mediante la desviación típica; cuanto más pequeña sea la desviación más centrado y fiable será el proceso y más leptocúrtica será la distribución.

Por otro lado, hay que tener en cuenta que el ámbito de la calidad se entiende que una unidad, producto o servicio es defectuoso si está fuera de los límites de especificación. Estos límites son aquellos entre los que pueden oscilar los valores individuales de la característica de calidad para que el producto sea considerado como aceptable. Son determinados por la dirección, los diseñadores del producto o la normativa legal vigente, y se pueden establecer de forma bilateral o unilateral, de acuerdo con un valor objetivo y unos límites que no se pueden superar. En este sentido, proporcionan una región de variabilidad fuera de la cual las unidades producidas no son válidas.

Los límites de especificación también se conocen como "límites de tolerancia" y por ello pueden expresarse de la forma siguiente:

Límites de especificación $=$ valor objetivo \pm tolerancia

\section{SIGMA QUAUTY LEVEL CALCULATION}

In this context, processes can be evaluated by means of the calculation of their sigma quality level which ranges from $1 \sigma$ level to $6 \sigma$ level. In what follows, the relation between $6 \sigma$ level and 3.4 nonconformities per million opportunities will be addressed.

When analysing a process, the quality features of interest usually follow a normal distribution, therefore the collected data are distributed around a central value (mean) with a certain spread or dispersion that can be measured through the standard deviation.

On the other hand, a unit, product or service will be considered as nonconformity when any of its quality features falls out of the specification limits. These limits, within which variations of quality features are accepted, are determined by the managerial board, the product designers or de current legal regulations. These limits are usually expressed in terms of a target value and a tolerance, according to the following expression: Specification limits $=$ target \pm tolerance, i.e.: 


$$
\begin{gathered}
\mathrm{LSE}=\text { valor objetivo }+ \text { tolerancia }= \\
\mathrm{VO}+\text { tolerancia } \\
\mathrm{LIE}=\text { valor objetivo }- \text { tolerancia }= \\
\text { VO }- \text { tolerancia }
\end{gathered}
$$

El porcentaje de unidades defectuosas se obtiene entonces calculando la probabilidad de obtener valores fuera de las especificaciones.

Se definen, además, los límites naturales del proceso, o límites de variación natural, como aquellos entre los que se mueve el proceso sin que sea posible mejorarlo. Dichos límites abarcan prácticamente la totalidad de la producción (se admite que contienen el 99,73\% de la misma). Si la característica que se controla se distribuye de forma $N(\mu, \sigma)$ los límites de tolerancia natural se sitúan a una distancia de $3 \sigma$ por encima y por debajo de la media, es decir, vienen dados por: $\mu \pm 3 \sigma$.

La comparación entre la variabilidad natural y la variabilidad exigida por las especificaciones se realiza mediante el estudio de la capacidad. La forma común de expresar la capacidad es en términos de índices o medidas adimensionales, que cuantifican el comportamiento del proceso teniendo en cuenta los parámetros del mismo y las especificaciones del producto. Uno de los primeros índices de capacidad se atribuye a Juran y está definido de la forma siguiente:

$$
C_{p}=\frac{L S E-L I E}{6 \sigma}
$$

Supuesto que el parámetro de interés es la media del proceso y que dicha media coincide con el punto medio del intervalo de especificación, la capacidad de un proceso indica su rendimiento cuando opera bajo control y la posibilidad que tiene de producir dentro de las especificaciones, es decir el índice $C_{p}$ mide la capacidad potencial del proceso.

$$
\begin{aligned}
& \text { Lower specification limit }(\mathrm{LSL})= \\
& \text { target }- \text { tolerance } \\
& \text { Upper specification limit (USL) }= \\
& \text { target }+ \text { tolerance }
\end{aligned}
$$

Therefore, the percentage of nonconformities can be determined by computing the probabilities of getting values out of the specification limits.

Let us introduce the concept of natural tolerance limits for the process, namely the inherent variation range of a process that cannot be reduced. When the quality feature to be controlled is normally distributed, considering as natural tolerance limits a range of three standard deviation $(\sigma)$ on either side of the mean $(\mu)$, i.e. $\mu \pm 3 \sigma$, will include almost the whole production of the process (exactly $99.73 \%$ of it).

The comparison of this natural tolerance range with the customer tolerance range leads to the study of the capability of a process. A measure of it, alleged to Juran, is the so called process capability index:

$$
C_{p}=\frac{U S L-L S L}{6 \sigma}
$$

Under the assumption that the specification target (the mid-point of the specification range) equates the process mean, this index $C_{p}$ serves as both an indicator of the process performance when operating on target and also as a measure of the potential capability of the process (the possibility of producing within the specification range): 
- Si $C_{p}>1$, el proceso es capaz: cuanto mayor es el índice, más capaz será el proceso de producir dentro de las especificaciones.

- Si $C_{p}=1$, el proceso es estrictamente capaz: el porcentaje de unidades que no cumplen las especificaciones es sólo del 0,27\% (27 de cada 10000 unidades), pero cualquier cambio en la media o en la dispersión incrementaría dicho porcentaje.

- Si $C_{p}<1$, el proceso no es capaz: en el proceso se obtienen más de 27 por cada 10000 unidades que no cumplen las especificaciones.

Los índices de capacidad tienen un papel similar a los niveles de calidad (medidos en cantidad de sigmas) ya que ambos tratan de traducir en números la relación entre el funcionamiento del proceso y las exigencias y especificaciones de los productos o servicios. De este modo, la diferencia entre las especificaciones, dividido por el valor de la desviación típica, proporciona el número de sigmas que comprende dicha diferencia. Por tanto, el nivel de calidad, expresado como nivel "k sigma", se obtiene dividiendo la mitad del intervalo de especificación entre la desviación típica (véase Figura 1). Desarrollamos a continuación la situación para distintos niveles de calidad.

Proceso centrado: La media del proceso coincide con el valor objetivo (VO: valor medio del intervalo de especificación).

Nivel de calidad 3 sigma. En este caso caben 6 desviaciones típicas $(6 \sigma)$ en el intervalo definido por los límites de especificación y el rendimiento del proceso es del $99,73 \%$.

$$
\begin{aligned}
P(\mu-3 \sigma<X< & \mu \\
& =P(-3 \sigma) \\
& =0,9986-0,0013 \\
& =0,9973
\end{aligned}
$$

- If $C_{p}>1$, the process is capable: the larger this index is, the more capable of producing output within the specification limits is the process.

- If $C_{p}=1$, the process just meets the specification limits: any shift in the mean or the spread will result in more nonconformities than 27 per 10,000 units.

- If $C_{p}<1$, the process is incapable: the output contains more than 27 nonconformities per 10,000 units.

Process capability index is closely related to sigma quality level: both aim to translate into figures the ratio between the process performance and the product or service requirements. In fact, almost the same elements are considered in the calculation of sigma quality level which can be defined as the number of standard deviations included in the tolerance:

$$
\begin{aligned}
S Q L=\frac{\text { Tolerance }}{\sigma} & =\frac{\frac{1}{2}(U S L-L S L)}{\sigma} \\
& =\frac{U S L-L S L}{2 \sigma}
\end{aligned}
$$

Some examples of different sigma quality levels are commented below:

Process operating on target: the target value (mid-point of the specification range) equates the actual mean of the process.

3 sigma quality level: six standard deviations $(6 \sigma)$ are included in the specification range and the process yield is $99.73 \%$ (see Figure 1).

$$
\begin{aligned}
P(\mu-3 \sigma<X< & \mu \\
& =P(-3 \sigma) \\
& =0.9986-0.0013 \\
& =0.9973
\end{aligned}
$$




\section{Figura 1/Figure 1}

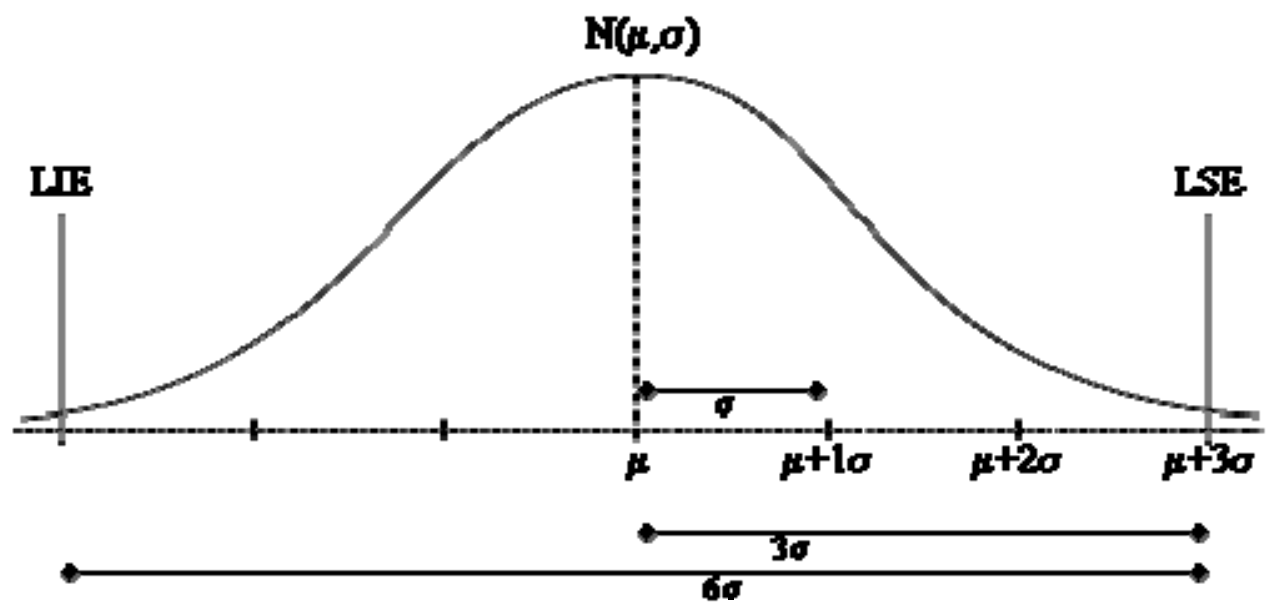

La proporción de unidades fuera de las especificaciones es de 0,0027 es decir, 27 de cada 10000 unidades o 2700 partes por millón (PPM), lo que supone 1350 PPM fuera de cada límite de especificación. En este caso el índice $C_{p}=1$.

Nivel de calidad 4 sigma. En este caso el rendimiento del proceso es:

$$
P(\mu-4 \sigma<X<\mu+4 \sigma)=0,99993
$$

La proporción de unidades fuera de las especificaciones es 0,000063 (63 PPM). En este caso $C_{p}=1,33$ pues caben 8 desviaciones típicas dentro de las especificaciones.

Nivel de calidad 6 sigma. Significa que en el intervalo definido por las especificaciones, $\mu \pm 6 \sigma$, caben 12 desviaciones y el porcentaje de unidades fuera de las especificaciones sería de 0,000000002 lo que equivale a 0,002 PPM. En este caso $C_{p}=2$.
The proportion of units that fall out of the specification range is $0.27 \%, 27$ per 10,000 units or 2,700 parts per million (ppm), since 1,350 ppm exceed the upper specification limit and other 1,350 ppm fail to exceed the lower specification limit. In this case the process capability index $C_{p}=1$.

4 sigma quality level: eight standard deviations $(8 \sigma)$ can be included in the specification range and the process yield is:

$$
P(\mu-4 \sigma<X<\mu+4 \sigma)=0.99993
$$

The proportion of units that fall out of the specification range is $63 \mathrm{ppm}$ and the process capability index $C_{p}=1.33$.

6 sigma quality level: in this case, twelve standard deviations $(12 \sigma)$ can be included in the specification range $\mu \pm 6 \sigma$, thus the process capability index $C_{p}=2$ and the process fallout is 0.002 ppm. 
Es evidente que el planteamiento anterior no coincide con los 3,4 PPM que proclama la metodología seis sigma. Ello es debido a que la media $\mu$ no siempre coincide con el $\mathrm{VO}$, es decir se admite que, debido a factores aleatorios, el proceso puede estar descentrado y desplazarse hasta $\pm 1,5 \sigma$ respecto del valor objetivo ${ }^{6}$.

Proceso descentrado: Cuando el proceso está descentrado $+1,5 \sigma$ (de igual forma se razona si el proceso está descentrado $-1,5 \sigma$ ), para un nivel de calidad 3 sigma habría 66811 PPM fuera de las especificaciones. Si la característica de calidad estudiada sigue una distribución normal con media $\mu^{\prime}=\mu+1,5 \sigma$, la probabilidad de que la característica estudiada esté dentro del intervalo definido por las especificaciones sería:

$P(\mu-3 \sigma<X<\mu+3 \sigma)=$ $\left\{X \sim N\left(\mu^{\prime}, \sigma\right)\right\}=P(-4,5<Z<1,5)=$ 0,9331894

En consecuencia, el porcentaje de unidades fuera de las especificaciones es de 0,0668106 que se traduce en 66810,6 PPM.

De la misma manera, un proceso 6 sigma supone un rendimiento del 99,99966\% y un porcentaje máximo de unidades fuera de las especificaciones de 0,0000034 (3,4 PPM) como se observa a continuación:

$P(\mu-6 \sigma<X<\mu+6 \sigma)=$ $\left\{X \sim N\left(\mu^{\prime}, \sigma\right)\right\}=P(-7,5<Z<4,5)=$ 0,9999966

Por otro lado, cuando el proceso está descentrado y la media del mismo no coincide con el punto medio entre las

\footnotetext{
${ }^{6}$ En el modelo 6 sigma de Motorola se parte de la hipótesis de que, a largo plazo, la media se desplazará, por razones de variabilidad, hasta 1,5 sigma.
}

Obviously, this result is much lower than the alleged Six-Sigma fallout (which is $3.4 \mathrm{ppm}$ ). This difference is due to the fact that the mean of the process do not always equate the target value because of random factors ${ }^{7}$ and, therefore, the process may not be operating on target.

Process not operating on target: when the difference between the target value $\mu$ (mid-point of the specification range) and the actual mean of the process equates $+1.5 \sigma$ (the same reasoning applies if it is $-1.5 \sigma)$, the fallout for a 3 sigma quality level will be 66,811 ppm. This is proved in what follows: if the quality feature under study is normally distributed with a mean $\mu^{\prime}=\mu+1.5 \sigma$, the probability of fallout will be:

$$
\begin{aligned}
& P(\mu-3 \sigma<X<\mu+3 \sigma)= \\
& \left\{X \sim N\left(\mu^{\prime}, \sigma\right)\right\}=P(-4.5<Z<1.5)= \\
& 0.93319
\end{aligned}
$$

Thus, the proportion of units that fall out of the specification range will be 66,811 ppm.

In the same vein, the yield of a 6 sigma quality level process not operating on target is $99.99966 \%$ and its fallout is 3.4 ppm:

$P(\mu-6 \sigma<X<\mu+6 \sigma)=$
$\left\{X \sim N\left(\mu^{\prime}, \sigma\right)\right\}=P(-7.5<Z<4.5)=$ 0.9999966

Moreover, when the process is not operating on target a different process capability index is used:

\footnotetext{
${ }^{7}$ Motorola's Six-Sigma model is based on the assumption that, in the long-term, the mean of the process can move up or down up to $1.5 \sigma$ from the target value.
} 
especificaciones, se suele definir un nuevo índice de capacidad de la forma siguiente:

$$
C_{p k}=\min \left\{\frac{\mu-L I E}{3 \sigma}, \frac{L S E-\mu}{3 \sigma}\right\}
$$

Los índices $C_{p}$ y $C_{p k}$ coinciden cuando el proceso está centrado, pero $C_{p k}$ es menor que $C_{p}$ en caso contrario. Si el proceso está descentrado de modo que $\mu^{\prime}=\mu+1,5 \sigma$ y el intervalo de especificación está situado en $\mu \pm 3 \sigma$ se obtiene

$$
\begin{aligned}
& C_{p k}=\min \left\{\frac{\mu^{\prime}-L I E}{3 \sigma},\right.\left.\frac{L S E-\mu^{\prime}}{3 \sigma}\right\} \\
&=\min \{1,5 ; 0,5\}=0,5
\end{aligned}
$$

Del mismo modo, si el intervalo de especificación es $\mu \pm 6 \sigma$, el índice $C_{p k}=$ 1,5 .

La Tabla 2 presenta, para distintos niveles de calidad, los índices de capacidad, el valor de PPM y el rendimiento, cuando el proceso está centrado y cuando está descentrado $\pm 1,5 \sigma$.

$$
C_{p k}=\min \left\{\frac{\mu-L I E}{3 \sigma}, \frac{L S E-\mu}{3 \sigma}\right\}
$$

$C_{p}$ and $C_{p k}$ are equal when the process is operating on target, but $C_{p k}$ is lower than $C_{p}$ otherwise. If the process is operating off target by a difference of $+1.5 \sigma\left(\mu^{\prime}=\right.$ $\mu+1.5 \sigma)$ and the specification range is set to $\mu \pm 3 \sigma$ :

$$
\begin{aligned}
C_{p k}=\min \left\{\frac{\mu-L I E}{3 \sigma}\right. & \left., \frac{L S E-\mu}{3 \sigma}\right\} \\
= & \min \{1.5,0.5\}=0.5
\end{aligned}
$$

Likewise, if the specification range is set $\tau \mathrm{o} \mu \pm 6 \sigma$, the index $C_{p k}=1.5$.

In Table 2, different sigma quality levels and their corresponding capability indices, fallouts and yields are presented both considering the process is operating on target and off target by a difference of $\pm 1.5 \sigma$.

\section{Tabla 2/Table 2}

\begin{tabular}{|c|c|c|l|c|c|c|}
\hline \multirow{2}{*}{$\begin{array}{c}\text { Nivel sigma } \\
\text { SQL }\end{array}$} & \multicolumn{3}{|c|}{ Proceso centrado / Process on target } & \multicolumn{3}{|c|}{$\begin{array}{c}\text { Proceso descentrado en } \pm 1,5 \sigma \\
\text { Process off target by } \pm 1,5 \sigma\end{array}$} \\
\cline { 2 - 7 } & $C_{p}$ & $\begin{array}{c}\text { PPM } \\
\text { defectuosas } \\
\text { Fallout (ppm) }\end{array}$ & $\begin{array}{c}\text { Rendimiento } \\
\text { Yield }\end{array}$ & $C_{p k}$ & $\begin{array}{c}\text { PPM } \\
\text { defectuosas } \\
\text { Fallout (ppm) }\end{array}$ & $\begin{array}{c}\text { Rendimiento } \\
\text { Yield }\end{array}$ \\
\hline 1,5 & 0,5 & 133.614 & $86,6386 \%$ & 0,000 & 501.350 & $49,8650 \%$ \\
\hline 2 & 0,66 & 45.500 & $95,4500 \%$ & 0,167 & 308.770 & $69,1230 \%$ \\
\hline 3 & 1 & 2.700 & $99,7300 \%$ & 0,500 & 66.811 & $93,3189 \%$ \\
\hline 4 & 1,33 & 63 & $99,9937 \%$ & 0,833 & 62.10 & $99,3790 \%$ \\
\hline 5 & 1,66 & 0,57 & $99,999943 \%$ & 1,167 & 233 & $99,977 \%$ \\
\hline 6 & 2 & 0,002 & $99,9999998 \%$ & 1,500 & 3,4 & $99,99966 \%$ \\
\hline
\end{tabular}


El nivel sigma se puede determinar tanto a partir del valor de PPM como del rendimiento del proceso utilizando las siguientes funciones de Microsoft ${ }^{\circledR}$ Excel:

Nivel sigma $=-$ INV.NORM.ESTAND

$\left(\mathrm{PPM} / 10^{6}\right)+1,5$

Nivel sigma $=$ INV.NORM.ESTAND

(RENDIMIENTO)+1,5

Donde el valor -INV.NORM.ESTAND $\left(\right.$ PPM $\left./ 10^{6}\right) \equiv$ INV.NORM.ESTAND(RENDIMIENTO) se conoce como valor $Z$ de referencia. La mayoría del software estadístico calcula este valor $Z$ de referencia, que indica el nivel sigma del proceso cuando está centrado. El nivel sigma cuando el proceso está descentrado se puede calcular de manera sencilla simplemente sumando 1,5 al valor $Z$ de referencia.

\section{SESSIGMAENUNSERMCIO SANTARIO}

La aplicación de la metodología seis sigma en un servicio de atención sanitaria es perfectamente posible si entendemos que, en general, un servicio es un proceso medible sobre el que se puede actuar. A pesar de la complejidad de un servicio como el que presentamos, en seis sigma encontramos pautas de actuación que nos ayudarán a tomar decisiones y a plantear líneas de mejora.

Tomaremos como referencia un Centro de Salud en el que hay un equipo de Atención Primaria compuesto por médicos de familia, pediatras (0-14 años), enfermeras, una matrona, un trabajador social, el servicio de extracción para análisis clínicos y el personal administrativo. La revisión de las encuestas de satisfacción, que se realizan periódicamente, permite detectar los fallos más significativos en la prestación del servicio sanitario. La información recogida
Moreover, sigma quality levels can be computed from both the process fallout (ppm) and yield by using any of the following Microsoft ${ }^{\circledR}$ Excel functions:

$\mathrm{SQL}=-\mathrm{NORM}$.S.INV(fallout $\left./ 10^{6}\right)+1.5$

$\mathrm{SQL}=\mathrm{NORM}$.S.INV(yield)+1.5

Where the value -NORM.S.INV (fallout $/ 10^{6}$ ) $\equiv$ NORM.S.INV (yield) can be referred to as benchmark Z-score. Most statistical software computes this benchmark Z-score, that indicates the sigma quality level for a process on target, instead of the sigma quality level when the process is operating off target. However, the latter can be easily calculated by just adding 1.5 to the benchmark Z-score.

\section{SIX-SIGMA IMPLEMENTATION IN A HEALTHCARE SERMCE}

In what follows, an example for the implementation of this methodology in a healthcare service is described. This implementation is perfectly possible bearing in mind that any service is a measurable process that may be monitored and controlled. Though its complexity, six-sigma provides with rules that guide the decision making process and the planning of future actions.

A primary health medical group (that includes family physicians, paediatricians, nurses, one midwife, one social worker, clinical laboratory technologists and administrative staff) will be taken as a reference. The results of the customer satisfaction survey that is carried out periodically in this healthcare centre is taken as the starting point of the improvement process. 
en dichas encuestas se estructura en los siguientes apartados:

- Accesibilidad (localización del Centro de Salud y facilidad para conseguir cita)

- Tiempos de espera

- Información recibida

- Trato y atención

- Cuidados: seguimiento y coordinación

- Profesionalidad del personal

Uno de los aspectos que se pretende mejorar, en la medida de lo posible, es "el tiempo de espera hasta entrar en la consulta" (los encuestados afirman que el tiempo medio de espera se sitúa alrededor de los 20 minutos). Para ello se decide formar un grupo de trabajo en el que participe todo el personal involucrado: médicos, enfermeras, auxiliares, personal administrativo, etc. Dado que resulta complejo evaluar el tiempo de espera de los pacientes (sobre todo si el tiempo se evalúa a partir de la opinión de los mismos), se opta por identificar y analizar qué factores influyen en el retraso. De este modo, en la ecuación $Y=f\left(X_{1}, X_{2}, \ldots \ldots . X_{n}\right)$ la variable dependiente $(Y)$ se asocia con el "tiempo de espera", mientras que las variables independientes $X_{1}, X_{2}, \ldots \ldots, X_{n}$ serán los factores que influyen, en mayor o menor medida, y cuya importancia trataremos de determinar.

De acuerdo con la metodología seis sigma, para estudiar este problema se describen las fases del ciclo DMAMC.

Definir: el objetivo que se persigue es reducir el retraso sobre la hora de cita y programar adecuadamente las citas.

Medir: en esta fase se recopila información relativa a la situación actual, con el fin de abordar y profundizar en el problema. Siempre que sea posible, los datos se preparan para ser tratados estadísticamente.
This survey shows that one of the indicators that should be improved is the time patients spend waiting for their turn (according to those surveyed, the average waiting time is about 20 minutes). Therefore, a working group is formed including all the personnel involved (physicians, nurses, and auxiliary and administrative staff) in order to identify those factors determining the patients' waiting time. Thus, in the equation $Y=f\left(X_{1}, X_{2}, \ldots \ldots, X_{n}\right)$ the dependent variable $Y$ represents the wait time, while the independent variables $X_{1}, X_{2}, \ldots \ldots, X_{n}$ are the determining factors whose influence or importance is being assessed.

According to Six-Sigma methodology, this problem should be addressed by following the DMAIC phases:

Define: the main goal aimed is to reduce the time the patients spend waiting for their turn by increase the punctuality and improving the scheduling procedure.

Measure: in this phase, information about the current situation of the evaluated process is gathered in order to detect the root causes of the problem. Thus, a brainstorming is used in order to identify the wait time's explaining factors. 
Como punto de partida se realiza un brainstorming para identificar las causas del retraso. Mediante un diagrama causa-efecto se agrupan estas causas en cinco grupos: Personal, Métodos, Material, Entorno y Máquinas y se elabora un diagrama causa efecto (diagrama de Ishikawa) como el que aparece en la Figura 2. Todos los motivos que se apuntan en el gráfico son situaciones habituales en el desarrollo de una consulta. Evidentemente la clasificación realizada no es exhaustiva y puede, y debe, revisarse si aparecen nuevas condiciones. Por otra parte, el diagrama causa efecto recoge las causas más importantes del problema, pero debe entenderse que dichas causas son sólo causas potenciales. En consecuencia, es necesario recoger datos para confirmar que las relaciones causa efecto realmente existen.
These factors are clustered in five groups (material, personnel, environment, methods and machines) and are represented in an Ishikawa cause-effect diagram (see Figure 2). All the elements shown in the diagram are usual situations that potentially may cause the problem; however, data should be gathered to confirm that the cause-effect relation actually exists.

\section{Figura 2. Diagrama causa-efecto / Figure 2. Ishikawa-effect diagram}

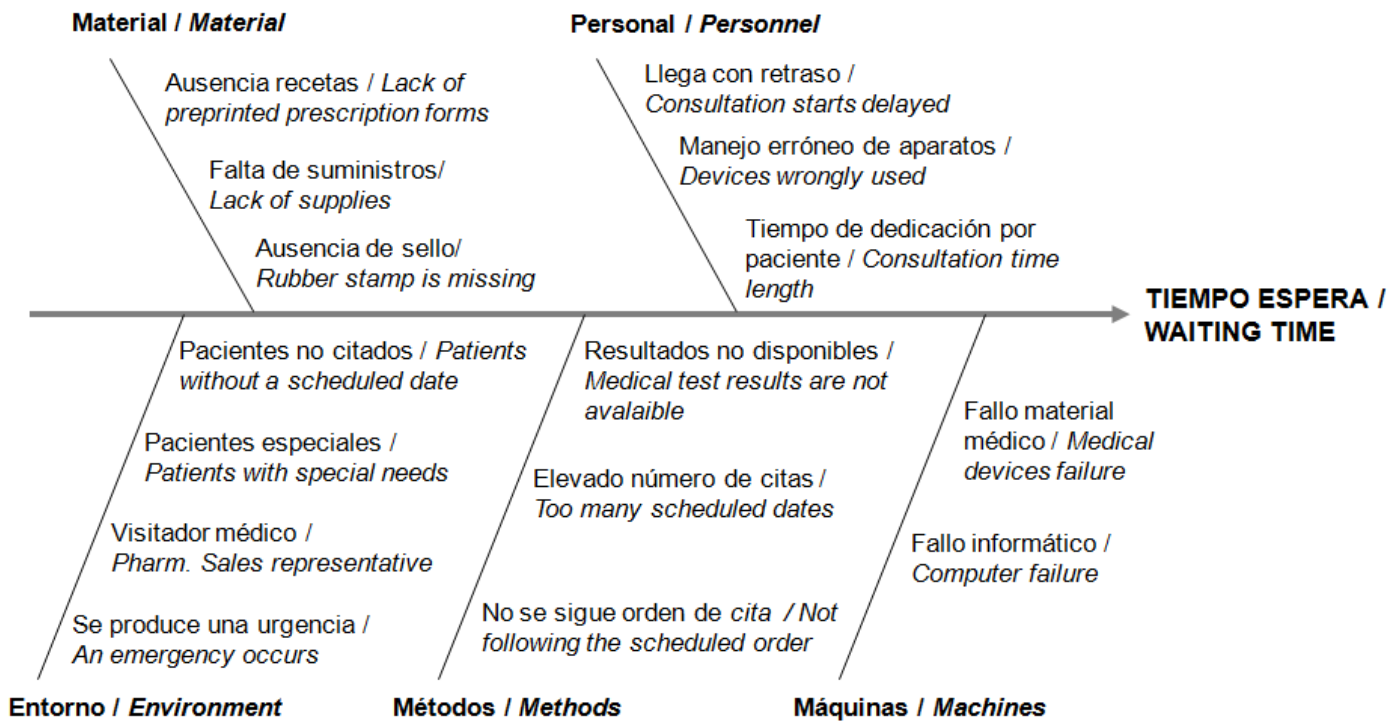

Entorno / Environment

Métodos / Methods

Máquinas / Machines 
Con el fin de disponer de información fiable, se selecciona una muestra de 20 días y se anotan las incidencias que se producen durante el desarrollo de la consulta, así como la frecuencia de cada una de ellas. También se registra el número de pacientes citados cada día (que se traslada diariamente de la administración a la consulta), y se contabiliza el número de pacientes que asisten a consulta sin tener cita así como el número de pacientes que fallan. A partir de los datos recogidos se realiza un estudio estadístico aplicando las herramientas adecuadas.

Analizar: en primer lugar se construye un gráfico de Pareto (Figura 3) con el fin de detectar las situaciones más relevantes sobre las que centrar la atención. Hay tres tipos de incidencias que acumulan alrededor del $80 \%$ de las frecuencias: "tiempo de dedicación por paciente", "llegada de pacientes no citados" y "no se respeta el orden de cita". Evidentemente, los dos últimos motivos están estrechamente relacionados y se condicionan mutuamente.
Therefore, a 20-day sample is selected and the frequency of each of these situations is counted. It is also registered the number of patients dated, the number of patients that attend to the Health Service without a previously scheduled date, and the number of patients that miss a scheduled date. All this information will be analysed by means of the appropriate statistical tools in the next step.

Analyse: first of all, a Pareto chart (see Figure 3) is used to visualise which are the most frequent situations that increase waiting times. The following three situations account for almost $80 \%$ : consultation time length, patients without a scheduled date, and not following the scheduled patients order, being the two latter tightly related and mutually conditioned.

\section{Figura 3/ Figure 3}

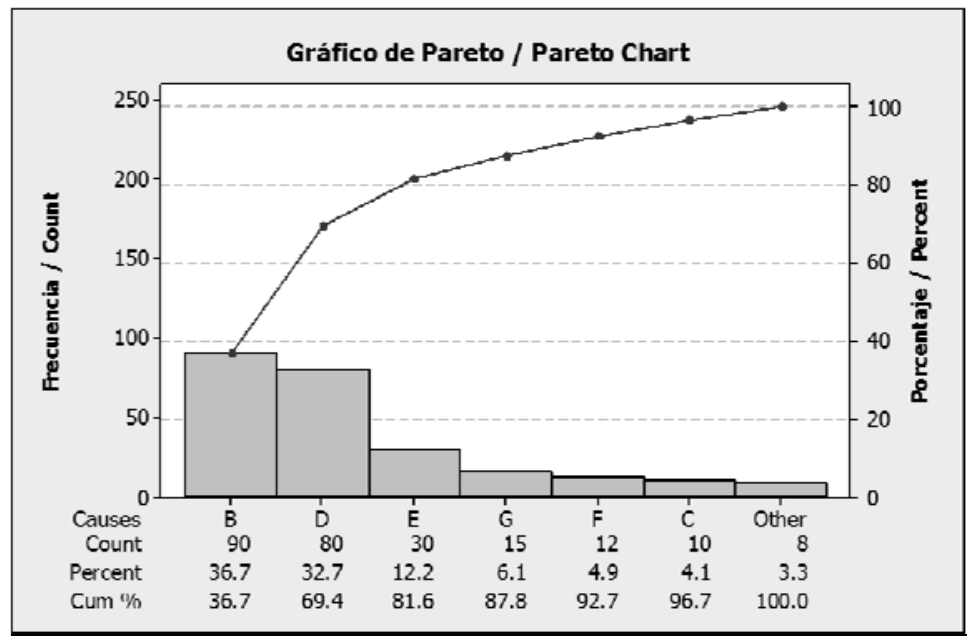

A: Retraso comienzo consulta / A: Consultation starts delayed B: Tiempo dedicación por paciente / Consultation time length C: Manejo erróneo de aparatos / Devices wrongly used D: Pacientes no citados / Patients without a scheduled date
E: No se respeta el orden / Not following the scheduled patients order

F: Resultados no disponibles / Medical test results are not available

G: Se produce una urgencia / An emergency occurs $\mathrm{H}$ : Otros / Others 
Por otra parte se analizan las variables "número de pacientes citados", "número de pacientes no citados" y "número de pacientes que no asisten" y se deduce "total pacientes atendidos". Para estas variables se realiza un análisis descriptivo que se recoge en la Tabla.3. De acuerdo con estos datos, se citan diariamente una media de 44,5 pacientes y se atiende una media de 50,8 pacientes por día. Además, ambas medias son representativas pues su dispersión relativa es muy baja $(\mathrm{CV}<8 \%)$.
On the other hand, the variables number of patients dated (DATED), number of patients without a date (NON-DATED), number of patients that miss a scheduled date (MISSING), as well as the total number of attended patients (ATTENDED) are summarized (see Table 3 ).

According to this data, the average number of patients dated per day is 44.5 while the average number of patients attended per day is 50.8. Both measures are highly representative since the relative dispersions of both variables are very low $(\mathrm{CV}<8 \%)$.

Tabla 3/Table 3

\begin{tabular}{|l|c|c|c|c|c|c|}
\hline Variable & $\begin{array}{c}\text { Media } \\
\text { Mean }\end{array}$ & $\begin{array}{c}\text { Desviación } \\
\text { estándar } \\
\text { Standard } \\
\text { deviation }\end{array}$ & $\begin{array}{c}\text { Coeficiente de } \\
\text { Variación (CV) } \\
\text { Coefficient of } \\
\text { Variation (CV) }\end{array}$ & $\begin{array}{c}\text { Mínimo } \\
\text { Minimum }\end{array}$ & $\begin{array}{c}\text { Mediana } \\
\text { Median }\end{array}$ & $\begin{array}{c}\text { Máximo } \\
\text { Maximum }\end{array}$ \\
\hline $\begin{array}{l}\text { Citados } \\
\text { Dated }\end{array}$ & 44,550 & 3,546 & $7,96 \%$ & 32,000 & 45,000 & 49,000 \\
\hline $\begin{array}{l}\text { No citados } \\
\text { Non dated }\end{array}$ & 9,000 & 3,584 & $39,82 \%$ & 5,000 & 9,000 & 21,000 \\
\hline $\begin{array}{l}\text { No asisten } \\
\text { Missing }\end{array}$ & 2,750 & 2,489 & $90,53 \%$ & 0,000 & 2,000 & 8,000 \\
\hline $\begin{array}{l}\text { Atendidos } \\
\text { Attended }\end{array}$ & 50,800 & 3,302 & $6,50 \%$ & 45,000 & 51,000 & 59,000 \\
\hline
\end{tabular}

Mediante el test de normalidad de Anderson-Darling podemos deducir que la distribución de la variable "pacientes atendidos diariamente" se ajusta a una distribución normal $(p=0,557)$. Por el contrario, la hipótesis nula de normalidad para la variable "pacientes citados" debe ser rechazada $(p \leq 0,005)$. La evolución conjunta de ambas variables se recoge en el gráfico de la Figura 4. Dicho gráfico pone de manifiesto que, prácticamente todos los días, acuden a la consulta más pacientes de los citados. Esta circunstancia influye en gran medida en el retraso y en el aumento del tiempo de espera, pues, dependiendo del tratamiento que se de a dichos pacientes, se puede alterar el orden fijado en las citaciones.
The Anderson-Darling normality test is conducted on both variables and the results indicate that the number of attended patients (ATTENDED) could be considered as normally distributed $(p=0.557)$. On the contrary, the null hypothesis of normality for the number of patients dated (DATED) should be rejected $(p<0.005)$. After plotting both variables in a line graph (see Figure 4), it becomes evident that, almost every day, the number of attended patients is higher than the number of those dated. Depending on how the patients without date are dealt with, this situation may increase greatly the waiting times of those dated. 


\section{Figura 4/ Figure 4}

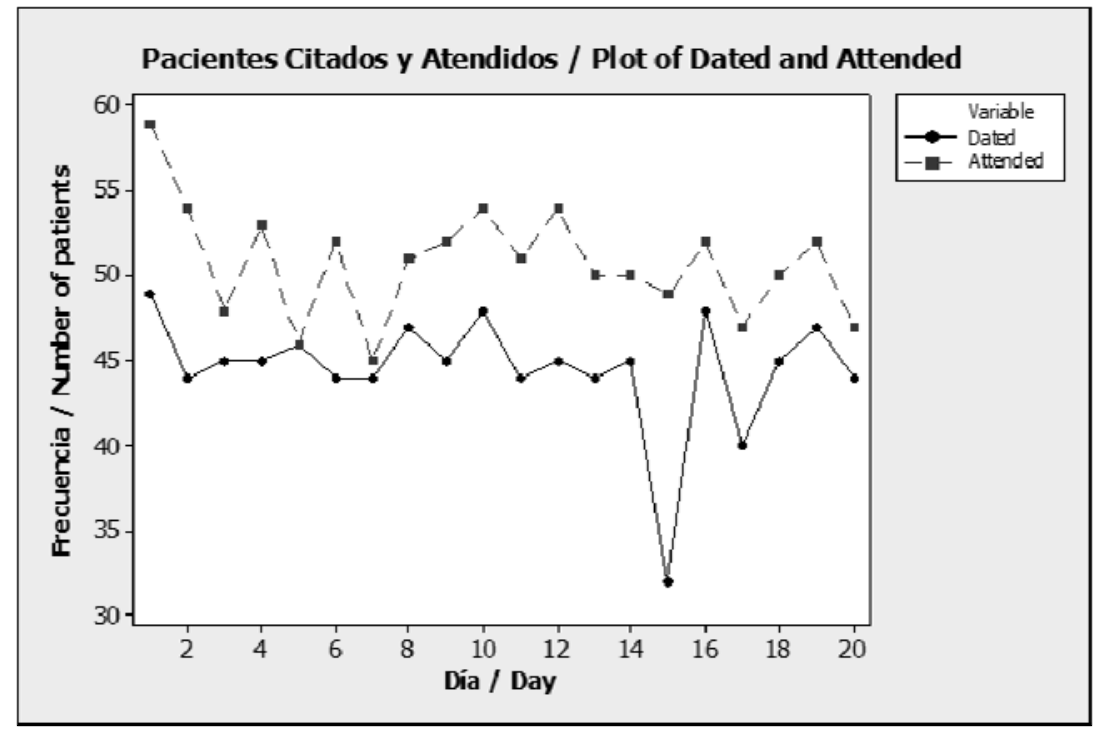

Es obvio, entonces, que la llegada de pacientes sin cita previa (salvo las urgencias), es un factor que afecta al correcto desarrollo de la consulta. Podemos asimilar esta situación a la de un proceso en el que se controla el porcentaje de unidades defectuosas (los pacientes que acuden sin cita) y construir un gráfico de control $p$. De este modo podemos estudiar y controlar si el porcentaje de pacientes no citados (calculado en relación al total de los atendidos cada día) se mantiene dentro de los límites estadísticos (situados a distancia de $k$ sigma respecto de la media estimada). Los gráficos de control constituyen una de las herramientas más importantes del control estadístico de procesos. Su finalidad es comprobar si un proceso opera bajo control y diferenciar la variabilidad natural (inherente al proceso) de la variabilidad no natural (debida a causas especiales). Cuando un proceso está en control estadístico es estable y previsible a lo largo del tiempo.
Thus, since the patients who have not a scheduled date interfere in the normal healthcare service, they could be controlled in the same vein as the industrial processes' nonconformities are. Control charts, which are one of the most important tools in statistical process control (SPC), allow to determine whether a process is currently under control, and also to distinguish between variation in a process resulting from common causes and variation resulting from special causes. One type of these charts, the p-chart, is used to monitor and control whether the proportion of nonconformities (in our case, the ratio of the number of patients without a date to the total number of attended patients per day) falls between the control limits (drawn at $k$ sigma from the mean of the proportions). 
En la Figura 5 se representa un gráfico de control $p$ con límites de control 2 sigma y 3 sigma. La observación correspondiente al día 15 aparece fuera de los límites de control (situación que puede deberse a la presencia de alguna causa "especial"). Se decide repetir el gráfico recalculando los límites de control una vez eliminada la información correspondiente a ese día. El gráfico resultante indica que el proceso está en control estadístico (Figura 6) y la línea central muestra que un $16,44 \%$ de los pacientes atendidos acudieron sin cita previa. Además, los porcentajes diarios representados en el gráfico se mantienen entre los límites de control de forma aleatoria, sin mostrar ningún patrón que sugiera un comportamiento especial en determinados días. Estos límites de control no son constantes, ya que tampoco lo es el número de pacientes atendidos cada día, y nos pueden servir de referencia para monitorizar y vigilar la situación futura.
In Figure 5, a p-chart with 2 sigma and 3 sigma control limits is plotted. There is just one observation, the one that corresponds to day number 15, that falls outside the outer control limits (possibly due to a "special cause").

If these special causes of variation can be identified and eliminated, it is normal to recalculate the chart limits with this observation omitted from the calculations and to scrutinize the revised chart (see Figure 6). The resulting chart indicates that the process is under control and the central line shows that $16.44 \%$ attended patients did not have a scheduled date. Moreover, all the data plotted in the chart fall randomly between the control limits and apparently do not follow any trend or special pattern. These control limits, which are not constant since the number of attended patients per day is also variable, can be taken as references to monitor the future situation.

\section{Figura 5. Porcentaje de pacientes no citados}

\section{Figure 5. Proportion of patients without date}

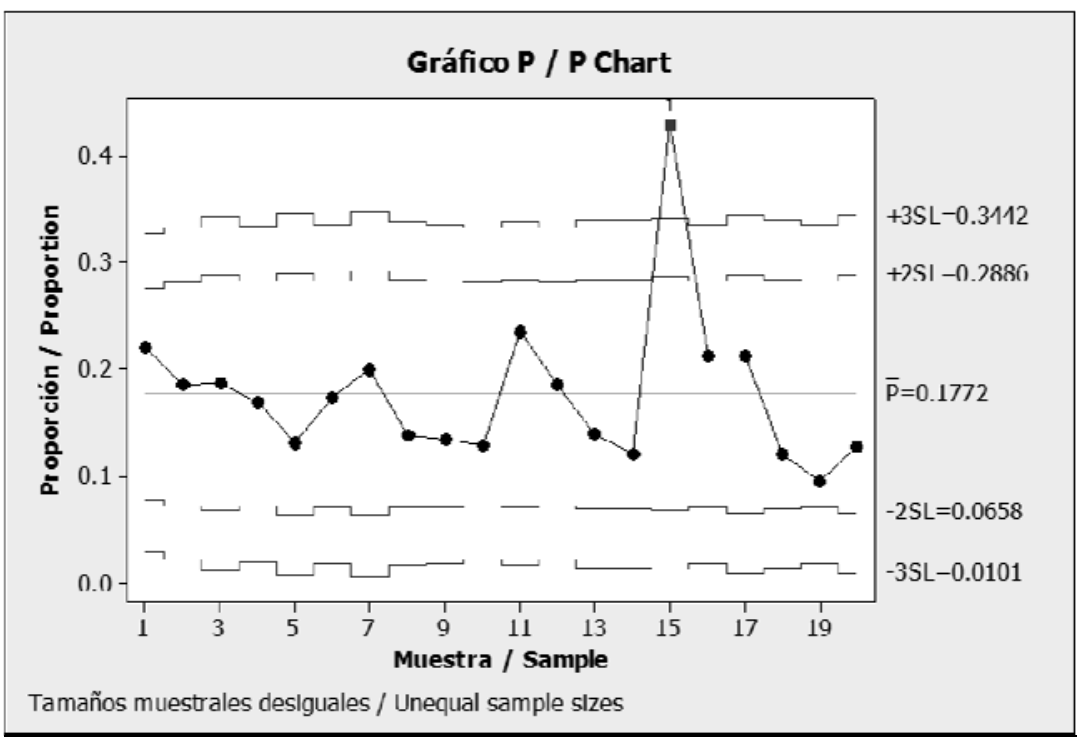




\section{Figura 6. Porcentaje de pacientes no citados (Ajustado) Figure 6. Proportion of patients without date (ajusted)}

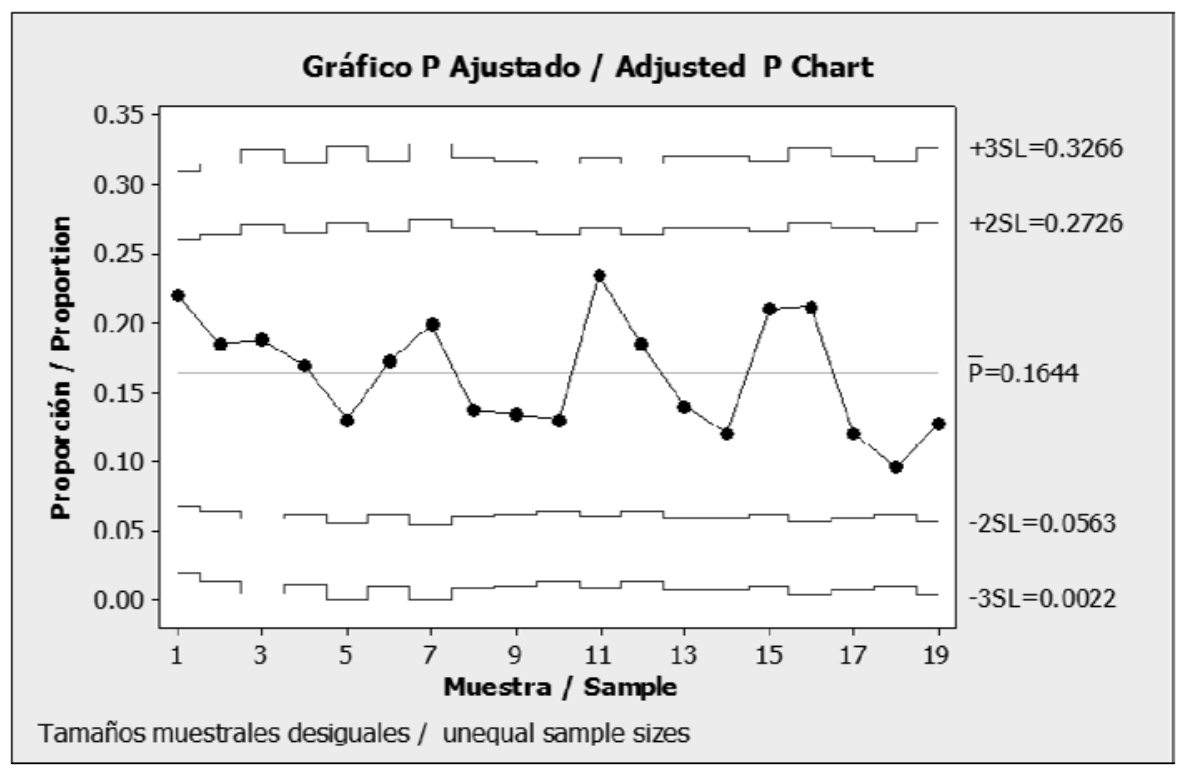

Los resultados anteriores ofrecen una visión más clara del problema planteado. El retraso en el tiempo de espera de los pacientes respecto a la hora de cita, se debe más a factores ajenos que a la propia programación de las citas. Es evidente que el número de citas asignadas cada día se programa en función de las horas que el médico debe estar en la consulta, y en el tiempo dedicado por paciente. Sin embargo, dado que la presencia de pacientes no citados supone un porcentaje del $16,44 \%$ se debe tener en cuenta este aspecto a la hora de programar las citas. Entendiendo la atención al paciente como un proceso afectado por este factor (que influye en el tiempo de espera), se puede calcular el nivel sigma del proceso. Para ello se estudia la capacidad del proceso correspondiente a $\sim$ una situación binomial y se obtienen los m resultados que aparecen en la Tabla 4.
All the previous results provide with a clearer vision of the addressed problem. The length of the waiting times are mainly due to other factors different from the scheduling of dates itself. Obviously, the number of dated scheduled per day are assigned depending on the physician's working time and the consultation time length per patient. However, the planning should also consider the patients who do not have a scheduled date since they account for $16.44 \%$ of the total attended.

In order to determine the sigma quality level of the process a capability analysis corresponding to a binomial situation is conducted (see the results in Table 4). 


\section{Tabla 4. Análisis de capacidad del proceso binomial: Resumen (nivel de confianza 95\%) / Table 4. Binomial process capability analysis: Summary (confidence level: 95\%)}

\begin{tabular}{|c|c|}
\hline \% Defectuosos I Nonconformities (\%) & $\mathbf{1 6 , 4 4}$ \\
\hline IC inferior / Confidence interval (lower limit) & 14,16 \\
\hline IC superior / Confidence interval (upper limit) & 18,93 \\
\hline Def PPM I Nonconformities (ppm) & $\mathbf{1 6 4 4 2 6}$ \\
\hline IC inferior / Confidence interval (lower limit) & 141597 \\
\hline IC superior / Confidence interval (upper limit) & 189319 \\
\hline Z del proceso / Benchmark Z-score & $\mathbf{0 , 9 7 6 4}$ \\
\hline IC inferior / Confidence interval (lower limit) & 0,8804 \\
\hline IC superior / Confidence interval (upper limit) & 1,0732 \\
\hline
\end{tabular}

Si el desarrollo de las consultas diarias no se viera afectada por la presencia de los pacientes que acuden sin cita, mejoraría la puntualidad en la atención pues, cuanto menor sea el porcentaje de dichos pacientes, mayor será el nivel sigma del proceso. En el caso que analizamos el nivel sigma se sitúa en 2,48 (valor $Z$ del proceso $+1,5=$ $0,9764+1,5)$, lejos del objetivo de un nivel de calidad 6 sigma.

Mejorar: las acciones de mejora deberían centrarse en establecer prioridades en la atención: en primer lugar y, salvo que se presente una urgencia, prestar atención a los pacientes con cita previa. De este modo estos pacientes serían atendidos a la hora asignada. Aunque esta forma de proceder suele ser habitual en las consultas, también es cierto que, en ocasiones, se mezcla el orden de llegada con el orden de cita, lo que ocasiona problemas y protestas. Por otro lado, es tarea del personal sanitario del centro de Atención Primaria concienciar a los pacientes de la necesidad de pedir cita para mejorar el funcionamiento de las consultas (salvo que la consulta sea urgente).
Should the daily consult schedule be not altered by the presence of patients without a date, the punctuality would increase and the waiting time would be reduced. Thus, the lower is the proportion of patients without a date, the higher the sigma quality level (SQL) of the process will be. For the current data, $\quad \mathrm{SQL}=$ Benchmark $Z$-score $+1.5=$ 2.48 , which is pretty far from the target of 6 sigma quality level.

Improve: the improvement actions should be focused on ensuring the fulfilment of the priority rule: unless an emergency occurs, the patients who have a scheduled date will be the first consulted, and those patients without a date will be consulted afterwards. Following this rule should guarantee that the patients dated are consulted on their scheduled time. On the other hand, the primary health healthcare service staff should raise public awareness on the need of having a scheduled date to improve the whole service. 
Controlar: se debería realizar un seguimiento para comprobar si mejora la puntualidad en la atención. Posteriormente habría que recoger de nuevo información para estudiar si la mejora ha sido efectiva. Para ello, las herramientas estadísticas vuelven a ser imprescindibles.

\section{CONCLUSIONES}

La metodología seis sigma es perfectamente aplicable a la asistencia sanitaria, pues constituye una metodología estructurada que combina distintas herramientas estadísticas y proporciona un nueva perspectiva para mejorar la atención al paciente. Mediante seis sigma se identifican los factores que intervienen en un proceso para que, al conocerlos y tratarlos, sea posible diseñar un servicio estándar, siempre que se mantengan las condiciones, y realizar modificaciones o adoptar medidas si estas condiciones cambian.

En este trabajo hemos querido demostrar que las herramientas estadísticas resultan imprescindibles en la implantación de seis sigma, porque aportan un enfoque analítico y contrastado para abordar los problemas que se presentan. Por otro lado, hemos expuesto el razonamiento estadístico en el que se sustenta el cálculo del nivel sigma y su relación con los índices de capacidad.

La puesta en marcha de esta metodología en un servicio sanitario no es una tarea individual, por el contrario requiere la colaboración de todas las personas implicadas en el proceso. Además, tal y como hemos planteado, no es necesario recurrir a complejas herramientas estadísticas para resolver los problemas, pues existen técnicas sencillas muy adecuadas para analizar los datos y extraer conclusiones.
Control: A follow-up procedure should be implemented to monitor the improvement in the patient waiting times: new data should be regularly gathered to check, by means of the appropriate statistical tools, if there has been an actual, significant, and stable improvement in punctuality.

\section{CONCLUSIONS}

Six-sigma methodology could be perfectly implemented in healthcare services since it is based on a structured methodology that combines different statistical tools and provides with a new approach for the service improvement. By means of six-sigma, the factors that potentially may interfere in a process are identified, analysed and controlled in order to design a standard service under certain conditions and, if these conditions change, make the appropriate changes to readapt the process to the new situation.

The aim of this paper has been to show how the statistical tools are essential when it comes to implement six-sigma methodology since they provide with an analytic and proved approach to any problem. Moreover, the statistical rationale behind the computation of the sigma quality level and its relation to the capability indexes has been also addressed.

The implementation of six-sigma methodology cannot be an individual task; on the contrary it requires the cooperation of all those involved in the patient care process. But, on the other hand, as it has been shown in our example, it does not require the usage of complex statistical 
Su utilización en esta propuesta nos ha permitido identificar los factores que intervienen en el aumento del tiempo de espera, para trabajar sobre el que más influye: la llegada de pacientes no citados. La información analizada revela que un $16,44 \%$ de los pacientes que se atienden cada día acuden a la consulta sin cita previa, situación que afecta al correcto desarrollo de la misma. Se debería tratar de minimizar el efecto de estos pacientes no citados, bien prestándoles atención al final de la consulta, bien exigiendo disponer de cita (salvo en casos urgentes).

Como reflexión final, si el objetivo que se persigue es mejorar la satisfacción del paciente, hay que determinar cuáles son las características o variables que condicionan esta satisfacción. Pero ello supone un cambio de actitud y un liderazgo que impulse su puesta en marcha y consiga el compromiso de todos. Solo si existe ese compromiso se podrán detectar los fallos y, en consecuencia, plantear alternativas de mejora. tools since there are simpler techniques that allow analysing the data and getting to conclusions. As an example of their implementation in healthcare service, a specific situation was presented (excessive wait time length), various factors that interfere in the process were identified, then those more influential were indicated (16.44\% patients have not a scheduled date) and, finally, improvement actions were proposed (ensuring the fulfilment of the priority rules).

Finally, it could be said that the aspects or variables that influence that satisfaction should be identified in order to improve the patient satisfaction. But doing so demands a change in attitudes and a leadership to foster the implementation of this methodology and to obtain the commitment of everyone involved. Only if that commitment exists, the problems will be detected and, as a consequence, alternative actions to fix them will be proposed.

\section{BIBLIOGRAFÍA/REFERENCES}

Antony, F., Kumar, M. y Cho, B. (2007). Six sigma in service organisations: Benefits, challenges and difficulties, common myths empirical observations and success factors. International Journal of Quality \& Reliability Management, 24(3), 294-311.

Buck, C. (2001). Application of Six Sigma to reduce medical errors. Proceedings of the 55th Annual Quality Congress of the American Society for Quality.

Carey, R.G. y Lloyd, R.C. (2001). Measuring quality improvement in healthcare. A guide to statistical process control applications. Ed. ASQ.

Chassin, M. (1998). Is health care ready for six sigma quality? The Milbank Quarterly, 76(4), 565591.

Henderson, G.R. (2006). Six sigma. Quality improvement with minitab. Chichester: John Wiley \& Sons.

Jiménez, V. et. al. (2007). Aplicación de las técnicas Lean-Seis Sigma para mejorar la logística sanitaria. Primer Congreso de Logística y Gestión de la Cadena de Suministro, Zaragoza. 
Mariño Navarrete, H. (2005). ¿Calidad Seis Sigma para el sector salud? Rev. Vía Salud, Ene-Mar, $31,17-22$.

Palacios, J.L. (2003). Función y aplicabilidad del control estadístico de calidad en los servicios sociales. Cuadernos de Trabajo Social, 16, 29-48.

Ramírez Valdivia, M.T., Pinto de la Sota Navarro, S.A., Serpell Bley, A. y Enberg, L. (2007). ¿Seis Sigma en hospitales chilenos? Rev. OIKOS, 11(24), 31-46.

Tennant, R., Mohammed, M.A., Coleman, J.J. y Martin, V. (2007). Monitoring patients using control charts: A systematic review. International Journal for Quality in Health Care; 19(4), 187-194.

Valdivia Pérez, A., Arteaga Pérez, L., Escortell Mayor, E., Monge Corella, S. y Villares Rodríguez, J.E. (2009). Análisis de las reclamaciones en atención primaria mediante el control estadístico de procesos. Revista de Calidad Asistencial, 24(4), 155-161.

Van den Heuvel, J., Doess, R.J.M.M. y Vermaat, M.B. (2004). Six sigma in a Dutch hospital: Does it work in the nursing department?" Quality and Reliability Engineering International, 20, 419426.

Vuori, H.V. (1996). El control de calidad en los servicios sanitarios. Conceptos y metodología. Barcelona: Ed. Masson S.A. 